Article

\title{
Challenges to Scaling Sustainable Private Equity Markets in Emerging Europe
}

\author{
Mihai Precup
}

Department of Economics, University of Paris 1 Panthéon-Sorbonne, 75231 Paris, France; mihai-calin.precup@malix.univ-paris1.fr or mihai.precup@yahoo.com

Received: 21 May 2019; Accepted: 22 July 2019; Published: 28 July 2019

check for updates

\begin{abstract}
The objective of this paper is to identify the main barriers to sustainable private equity market development in emerging European countries. The cross-country panel data analysis that was used in this paper will focus on the main determinants of the private equity investments over the period 2000-2013. We followed the methodology developed by Gompers and Lerner in order to estimate a panel data model with fixed and random effects. Starting from the existing literature, we analyzed variables that were confirmed by the previous studies and we also introduce new variables, such as the corruption index, uncertainty index, and regulation. The results of our study confirmed the existing hypothesis regarding the barriers to private equity development, such as the unemployment rate, the lack of exit mechanisms due to the low level of market capitalization, and the corruption.
\end{abstract}

Keywords: private equity; sustainable investments; market capitalization; unemployment rate; corruption

\section{Introduction}

The private equity market in Eastern European countries accounted for only $3.4 \%$ of the total investments in this sector at the European level in 2016. The Figure 1 shows that the crisis has produced a sharp contraction in the growth of private equity in these countries, from 2.4 billion euros in 2009 to 1.3 billion euros in 2010 .

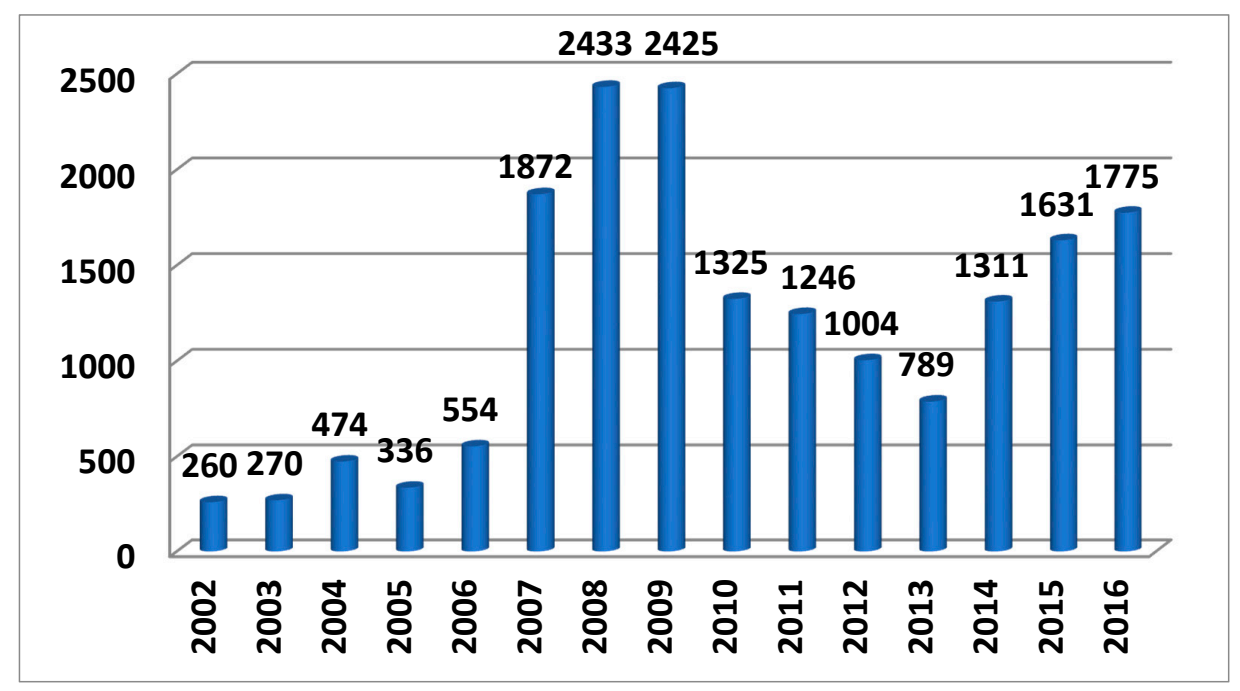

Figure 1. The evolution of private equity investments (millions of euros) in Eastern Europe [1]. 
This research focuses on the evolution of sustainable investments in the private equity market in Eastern Europe. This study has the following objectives: (i) to identify the determinants and the barriers of private equity in emerging Europe; (ii) compare the results that were obtained in this research with those that were reported by the relevant literature in the private equity sector; and, (iii) to describe the main barriers and challenges to developing sustainable private equity markets in Emerging Europe.

A sustainable private equity market is promoting sustainable investments that are socially responsible investments. We aim to analyze a private equity market that is incorporating environmental, social, and governance (ESG) factors into investment decisions. In a sustainable private equity market, during the investment decision, the private equity funds are considering factors, such as the job creation, improving energy savings, improving quality control for the services provided resulting in improving health, and consumer satisfaction.

Most of the previous studies focused on analyzing the determinants of venture capital in developed countries and very few studies have tried to use the same methodology to identify the main barriers for a sustainable private equity market. Furthermore, very few studies cover Eastern European countries.

The results of this work will provide an image of the main factors that have had a decisive influence on the evolution of private equity during the crisis in the Eastern European countries. This research will also make recommendations for Eastern European governments for improving the macroeconomic context of the sustainable private equity market in these countries.

For this study, we have developed a panel-type econometric model that includes variables from private equity literature, such as the unemployment rate or market capitalization, as well as new variables, such as the uncertainty index or productivity. The sustainable development of private equity investments in Emerging European countries is based on the improvement of the fiscal, legal, and regulatory framework that can encourage entrepreneurship, innovation, competitiveness, and long-term employment in these countries.

A sustainable private equity market can represent a financing alternative for companies that are located in Eastern Europe, since the development of these companies is highly dependent on bank financing. The role of private equity is also very important in financing start-ups, as well as in financing big companies. In addition, this type of investment brings both the capital and expertise that are necessary for developing a business and creating sustainable jobs.

Our empirical analysis of panel data consists of estimating fixed effects models and random effects models. The fixed effects models, as well as the random effects models, are set up based on the significance of the variables on the evolution of the private equity market in Eastern European countries. Subsequently, the Hausman test is used to choose the most appropriate model between the fixed effects model and the random effects model. In our research, we group all the relevant emerging European countries in to eight groups, and we used panel data to analyze 112 observations that were collected between 2000 and 2013 in Eastern European countries.

Our study provides three significant contributions to the literature on private equity investments. The first one is that this is one of the first studies to analyze the private equity drivers in Eastern Europe. Most of the studies focus on western countries and also in analyzing the venture capital investments, which is a subcomponent of the private equity investments. The second contribution of our study is that our panel data model has two dimensions: a temporal dimension of the evolution of the investments covering a period of 15 years and a spatial dimension covering eight groups of eastern European countries. We manage to build a reliable database using the information that was provided by the European Venture Capital Association and the Thomson Reuters. Finally, our theoretical analysis, although inspired in previous studies, adds a number of new macroeconomic variables. In particular, it emphasizes that the private equity funds during the investment process take into account variables, such as the corruption index, the uncertainty index, and the regulation, which are very relevant for scaling sustainable private equity markets in emerging Europe. 
This research is organized as follows: the next section will present the main drivers of the sustainable private equity market in emerging Europe. Afterwards, we will present the main findings of the current literature in relation to the drivers of the venture capital and, in general, of the private equity market. We will describe the methodology and will describe and compare the fixed effects models and random effects models. Section 5 explains the results of our econometrical models and Section 6 concludes the research paper and identifies the main barriers and challenges in developing sustainable private equity markets in Emerging Europe.

\section{The Main Drivers of the Sustainable Private Equity Market in Emerging Europe}

\subsection{The Return Offered by Private Equity Investments Is a Stimulus for Investors}

Private equity investments typically offer higher returns than other asset classes, such as listed assets.

Table 1 shows that the performances offered by private equity funds were quite high in European countries. Patrick [2] showed that private equity investments offer a higher return than that offered by listed shares thanks to a "non-liquidity" premium of $3.5 \%-4 \%$, in a study prior to the economic crisis, which is added to the price at which the shares are traded in a company that has been subject to a private equity investment. This "illiquidity" premium is closely linked to a long horizon, generally 10 years, for which private equity investments are made as compared to investments in capital markets with a short horizon (days, and sometimes even hours).

Ljungqvist and Richardson [3] study the performance of the largest institutional investors in private equity in the United States (U.S.) and they considered a sample of 73 funds for a period running between 1981 and 1993. This research argues that the private equity generates excess returns on the order of five to eight percent per annum relative to the aggregate public equity market.

However, the research that was developed by Phalippou and Gottschalg [4] show that a large part of performance is driven by inflated accounting valuation of on-going investments, and we find a bias towards better performing funds in the data. Phalippou and Gottschalg [4] argue that the private equity funds underperform the S\&P 500 and this conclusion contradicts the results that were obtained by Ljungqvist and Richardson [3].

Harris et al. [5] study the private equity performance of nearly over 1400 U.S. buyout and venture capital funds and they compared their results with the listed stocks performance. One of the main conclusions was that the private equity funds being VC fund or LBO funds outperformed the S\&P 500 on average with $20 \%$ to $27 \%$ over a fund's life and more than $3 \%$ annually.

Table 1. Net Internal Rate of Return (\%) aggregated by vintage of private equity funds [6].

\begin{tabular}{cc}
\hline & Net IRR (\%) \\
\hline $1990-1994$ & $15.5 \%$ \\
\hline $1995-1999$ & $9.8 \%$ \\
\hline $2000-2004$ & $13.7 \%$ \\
\hline $2005-2009$ & $4.9 \%$ \\
\hline $2010-2013$ & $3.9 \%$ \\
\hline
\end{tabular}

In Europe, The European Alternative Investment Fund Managers Directive (AFIM) address the regulation of private equity funds and hedge funds. According to this directive, the managers must have minimum capital and use the services of a depositary. They must also set up a valuation procedure that is reviewed by a third party. The European regulator considered that, in 2015, both hedge funds and private equity funds activity were shadow banking, even if they do not belong to the same logic or the same horizon of investment. 
In addition, the financial regulation that was introduced by the Basel II and III Agreements for the banking sector and by the Solvency II Directive for insurance groups and European pension funds has endangered the raising of funds for private equity. The capital requirements for financial institutions increase for amounts that were placed in private equity, which can be a constraint for fundraising by financial institutions. Despite these regulatory constraints, financial institutions are still attracted by the profitability that is offered by private equity, particularly by the LBO sector.

The manager of an investment fund that has publicly traded shares in its portfolio must face a fundamental risk that is related to the financial health of the company issuing the shares as well as a market risk. The manager of a private equity fund is very familiar with the company; therefore, the counterparty risk is less important. In addition, the market risk is almost non-existent, because these shares are not listed.

Kevin [7] shows the existence of an information asymmetry related to the private equity investments. Basically, the author considers that the management of a company has more information about the results of the company than a private equity fund. This should trigger a discount in the acquisition price, which would protect the private equity fund in the case of a downside scenario.

Amit et al. [8] studied the ability of private equity funds to reduce the cost of informational asymmetries in selecting and monitoring investments, as well as in choosing the exit strategies. The authors suggest that the managers should be also have a large a stake in the venture in order to reduce the informational asymmetries.

Cumming and MacIntosh [9] pointed that the information asymmetry between the management of the company and the private equity funds is the main decision factor in choosing the exist strategy. The research that was lead by Elisabete et al. [10] and Cumming [11] also showed that the role of the information asymmetry is crucial in building scenarios for exit and returns for the private equity funds.

In the case of divestment, investors are free to choose the exit strategies (IPO, industrial sale, secondary LBO, etc.) and timing (investors have the opportunity to wait for more favorable economic conditions).

The good returns that are offered by private equity investments, particularly in the LBO sector, are also explained by the fact that investors (Limited Partners) and managers (General Partners) are active players throughout the investment period. For example, in the event that the company that is the subject of the private equity investment encounters difficulties due to the economic context, the GP and the LP can actively intervene in its management and help it to reformulate the business plan (this is the concept of a Value Added Investor).

\subsection{The Management Is a Key Element for the Success of a Private Equity Investment}

The role of the management of a company that is the subject of private equity investment has significantly increased during the last crisis. During this period, the qualities of good management were mandatory to set up commercial and economic strategies in order to develop the companies that are not listed on the stock exchange, thus allowing them to develop and increase the investment value.

Private equity investment funds must develop a relationship of trust with the management of the target company. Thus, the managers must consider any intervention on the part of investors to establish the development strategy of the target company as auspicious.

Smith [12] states that the management of the target company should hold shares in the target company, as this will increase the probability to align the interests between the investors and the company's management.

Kaplan et al. [13] show that an investment provides high returns when the interests of the managers and the venture capital funds are aligned. However, their research concludes that the venture capital funds should place more weight in the business than on the management team.

The investors must ensure that the managers are sufficiently motivated to use all of their know-how for business development. The two parties negotiate a management package that defines the role of managers in the company, as well as their remuneration in relation to the degree of success of the 
investment in order to discuss and meet the expectations of the managers in terms of responsibilities and pecuniary requirements. It is also important to mention that the management package contains reward mechanisms, but also sanctions for managers during the investment period.

The negotiations between the investment fund and the managers of the companies make it possible to establish reward mechanisms for the companies, in the event that they decide to leave the company. In European law, managers' reward mechanisms are represented by share subscription warrants (BSAs), which give the holder the right to acquire one or more shares of a company at a fixed price and for a given period of time. The objective of this mechanism is to reward the management of a company following the achievement of the pre-established objectives, in terms of the profitability of the investment or the operational profitability of the company (EBITDA).

In addition, managers can benefit from preferred shares that are issued to reward them with the payment of dividends, thus limiting the possibilities of increasing their shareholding in the company's share capital. As mentioned above, the management package also includes corrective clauses for managers, such as bad leaver or good leaver, which are included in the Shareholders Agreement. These clauses aim to organize the conditions in which investors buy shares that are held by managers who are leaving the company due to misconduct or resignation.

There is a special category of managers, known as Operating Partners, who are experienced and who are generally chosen for the Board of Directors or the Supervisory Board of the company targeted by private equity investment. They help existing managers to build a long-term vision and define a new business plan. Operating Partners also play a long-term liaison role between the team that defined the strategy and ensured its financing and management of the company, being responsible for the implementation of the strategy.

Several private equity funds have hired famous names, such as Operating Partners or consultants. For example, Louis V Gerstner Jr, former IBM president, became the president of Carlyle in 2007. Another example is Paul O'Neill, former Secretary of State at the US Treasury, who, since then, has become a special advisor for the Blackstone Group.

\subsection{The Role of Private Equity Investments in Long-Term Job Creation}

Most of the time private equity investments take sustainability filters into consideration as these investments stimulate growth for sustainable companies that provide long-term jobs at fair wages while addressing workplace inequalities and risks. The emerging European countries also face an urgent need to provide improved social services to a growing middle class.

However, the information in the report published by Kearney [14] states the opposite. Table 2 shows that the private equity firms in the European Union and the United States of America have had a positive impact on the real economy between 2000-2007, because private equity investments have pursued the rapid development growth of the company, investing heavily both in the R\&D sector and in the company's external development, especially internationally, according to this annual report published by Kearney [14].

Table 2. European Union: annual job dynamics [14].

\begin{tabular}{cc}
\hline $\mathbf{2 0 0 7}$ & Annual Job Dynamics \\
\hline EU mean & $2.9 \%$ \\
\hline Private Equity & $5.4 \%$ \\
\hline
\end{tabular}

In the European Union between 2000 and 2007, companies in the portfolio of a private equity fund created more jobs than the European average. The ratio was $5.4 \%$ to $2.9 \%$, with $5.4 \%$ being the growth rate of jobs in privately owned companies as compared to the European average of $2.9 \%$.

Engel and Keilbach [15] show that the target company shows higher employment growth rates once a venture capitalist is involved. 
Bertoni et al. [16] state that the VC investments have a positive impact on the growth of employment. The authors focus on the Italian market and they conclude that, in general, after the first round of VC investment, there is a significant impact on the growth of employment for the target company.

The management of the target company, the return on private equity investments, and the long-term job creation, as well as the role of these investments in the financing of the real economy, are key factors that ensure the sustainability of the private equity market.

\section{Literature Review}

As described in Table 3, our research and methodology are inspired by the work of Black and Gilson [17], Gompers and Lerner [18], Jeng and Wells [19], Romain and La Potterie [20], Félix et al. [21], and Bernoth and Colavecchio [22]. These research studies mainly focus on the phenomenon of venture capital in developed countries. Our objective is to complete the literature by analyzing the sustainability of the private equity market in European Emerging countries.

Table 3. Literature review.

\begin{tabular}{|c|c|c|c|c|c|c|}
\hline Determinants & $\begin{array}{l}\text { Black and } \\
\text { Gilson } \\
\text { (1998) }\end{array}$ & $\begin{array}{c}\text { Gompers } \\
\text { and Lerner } \\
(1998)\end{array}$ & $\begin{array}{c}\text { Jeng and } \\
\text { Wells (2000) }\end{array}$ & $\begin{array}{c}\text { Romain and } \\
\text { de La } \\
\text { Potterie } \\
(2004)\end{array}$ & $\begin{array}{l}\text { Félix et al. } \\
\text { (2007) }\end{array}$ & $\begin{array}{c}\text { Bernoth and } \\
\text { Colavecchio } \\
\text { (2014) }\end{array}$ \\
\hline Economic growth & & + & $\varnothing$ & + & + & $(\mathrm{W}:+)(\mathrm{E}: \varnothing)$ \\
\hline Market capitalization & + & & $\varnothing$ & & + & $(\mathrm{W}:+)(\mathrm{E}:+)$ \\
\hline Number of IPOs & + & $\varnothing$ & + & & + & \\
\hline Number of M\&A & & & & & + & \\
\hline Number of write-offs & & & & & $\varnothing$ & \\
\hline Short term interest rate & & - & & + & & $(\mathrm{W}: \varnothing)(\mathrm{E}: \varnothing)$ \\
\hline Long term interest rate & & & & + & + & \\
\hline Unemployment rate & & & & & - & \\
\hline Tax rate & & - & $\varnothing$ & & & $(\mathrm{W}: \varnothing)(\mathrm{E}:-)$ \\
\hline$R \& D$ expenditure & & + & & + & $\varnothing$ & \\
\hline Number of patents filed & & & & + & & \\
\hline Entrepreneurial activity & & & & + & $\varnothing$ & \\
\hline Labor market rigidity & & & - & - & & $(\mathrm{W}:-)(\mathrm{E}: \varnothing)$ \\
\hline Value of pension funds & & & + & & & \\
\hline
\end{tabular}

Black and Gilson [17] analyze the main drivers for venture capital investments in the United States. The two authors conclude that a developed stock market is a determining factor in the evolution of venture capital investments, because it can offer to the venture capital funds attractive opportunities to exit from the capital of a company and to obtain interesting returns for their investment.

Both of the authors show the existence of a positive and statistically significant correlation between the number of stock market listings (IPOs) in year $t$ and the sum of investments that are made by private equity funds in the United States (US) during the year $t+1$. They even condition the development of the venture capital phenomenon to the existence of a dynamic stock market. In this logic, these authors explain the competitive advantage of the United States to attract investment to finance venture capital activity due to the existence of a dynamic stock market (NASDAQ), which offers investors interesting possibilities to leave the capital of a company by an IPO.

Gompers and Lerner [18] study the evolution of venture capital activity on the American continent; however, they take the period 1969-1994 into account. The main variables that they analyze are: the stock market quotations of the previous period, the economic growth of the previous period (expressed as a change in GDP in real terms), the yield on US Treasury securities of the prior period, i.e., the short-term interest rate, and the level of capital gains taxation.

The study that was carried out by these two authors confirms the positive effect of the economic growth of the previous period on the risk capital of the current period. At the same time, they statistically indicate the negative relationship between venture capital and the variables that are 
represented by the level of taxation on capital gains and the short-term interest rate. However, Gompers and Lerner [18] failed to statistically validate a relationship between the number of stock market quotations in $\mathrm{t}-1$ and the intention of investment funds to raise resources through venture capital activity in $\mathrm{t}$.

In their previously cited study, Gompers and Lerner [18] introduce research and development (R\&D) spending in the US public sector. The econometric model, as being significant and having a positive impact on the evolution of venture capital investments in the United States, validates this variable.

For their part, Jeng and Wells [19] take into account a sample of 21 countries during the period 1986-1995 in order to identify the main factors of decisive importance in the evolution of the venture capital phenomenon. These authors analyze the meaning of variables, such as market capitalization and the number of stock market quotations, the rate of economic growth, the rigidity of the labor market, the absolute value of pension funds, and the level of taxation on capital gains. Access to stock market quotations (IPO) is considered by both authors as being the most important factor in the decision-making process of investment funds to raise resources for venture capital activity.

The two authors also consider that the rigidity of the labor market represents an obstacle in the development of venture capital activity. On the other hand, the absolute value of pension funds is also an important factor over time, but it has not been validated for each country. However, they failed to validate a significant relationship between venture capital trends and variables, such as economic growth, market capitalization, and the level of capital gains taxation.

Romain and La Potterie [20] extended the study of previous authors and tried to identify the determining factors of venture capital activity for a sample of 16 countries between 1990 and 2000, countries that were part of the Organisation for Economic Co-operation and Development. The main variables that were used in the econometric model of these two authors are the economic growth rate, the short-term interest rate, the long-term interest rate, the growth rate of R\&D expenditure, the number of patents registered, the rigidity of the labor market, and the level of entrepreneurial activity.

The research that was coordinated by Félix et al. [21] focuses on the European continent and analyzes a group of 23 countries over the period 1992-2003. These authors are among the few people who have focused on the European space to understand the main determinants of these investments. In this sense, they have constructed an econometric model that tests variables, such as economic growth rate, long-term interest rate, market capitalization in absolute terms, research and development (R\&D) expenditures, unemployment rate, the number of stock market listings, the number of mergers and acquisitions, the write-offs, as well as the share price/book value ratio and the index of entrepreneurial activity.

Félix et al. [21] confirmed the results that were obtained by the previous authors: economic growth and market capitalization have been validated as factors that determine the evolution of venture capital investments on the European continent. The number of stock market listings and the mergers and acquisitions transactions have also had a significant impact on the venture capital phenomenon. The long-term interest rate and the unemployment rate have also been statistically validated as having a positive impact on the venture capital. However, the R\&D expenditures, the level of development of the entrepreneurial activity, the share price/book value ratio, and the number of bankruptcies have not been statistically validated in the econometric model of the two authors.

\section{Literature Review for the Private Equity Investments in Eastern Europe}

The recent work by Bernoth and Colavecchio [22] compared the determinants of the private equity market in Eastern European countries with those of Western European countries. The authors used a panel data estimate to analyze 14 countries between 2001 and 2008. They found similarities and differences in the determinants of private equity in Western and Eastern Europe. Their results suggest that commercial bank lending, market capitalization, single-wage costs, and corporate tax rates are important determinants of private equity activity in Western Europe, as well as in Eastern Europe. 
Karsai [23] provides an overview of the evolution of the private equity and venture capital markets in Eastern European countries between 2002 and 2008. He speculates on the future of this industry in the region after the crisis. According to him, the decline of the private equity market in the region during the crisis was to be reduced by the large amounts that were raised. In contrast, the author predicted a lack of resources to set up private equity funds during the crisis.

Vătavu [24] also analyzed 79 companies that were listed on the Romanian capital market over the period 2003-2014 and concluded that the financial crisis had a significant impact on their financial performance and that these companies had to change their capital structure and began to avoid using borrowed funds to develop their projects, which was an additional burden for the shareholders.

Diaconu [25] show that the private equity market in Central and Eastern Europe is far from being considered to be a developed market. This research identified the main challenges of this market, such as the modest proportion of innovative companies and the low levels of R\&D investments.

\section{Data and Research Methodology}

\subsection{Data}

Data on private equity investments was collected for 15 countries in Eastern Europe: Bulgaria, Czech Republic, Poland, Romania, Baltic States (Estonia, Latvia Lithuania), States of the former Yugoslavia (Serbia, Bosnia and Herzegovina, Slovenia, Croatia, FYROM), Ukraine and Hungary, and Slovakia. The initial sample of Eastern European countries had to be reorganized into eight groups of countries, due to the reduced availability of data in the EVCA (European Venture Capital Association) reports. We have set up our own data base by taking the information that was obtained from the Thomson Reuters database concerning private equity activity in Eastern Europe, as well as the annual reports that are produced by the EVCA (European Venture Capital Association).

The sample selected for private equity investments has 112 observations that cover the period 2000-2013 with an annual data frequency.

The database of Eurostat used to collect the independent variables, such as the GDP, in real terms, the interest rate, the unemployment rate, the $R \& D$ expenditure, the market capitalization, as well as the productivity (the value added produced by an employee in a year). The corruption index was collected from the cpi.transparency.org database. The variable representing "uncertainty" takes the values of the index developed by Baker et al. in 2013 [26] for Europe. The World Bank's database was mainly used to obtain information regarding the level of legislative and economic regulation for the countries in Eastern Europe.

\subsection{Research Methodology}

In this research paper, we use panel data analysis that includes both a horizontal dimension (i) and a temporal dimension $(t)$. The basic structure for analysis of a panel data regression is the following:

$$
\begin{gathered}
\text { Private equit }_{i t}=\beta_{0}+\beta_{1} \text { MarketCapitalisation }_{i t}+\beta_{2} \text { Unemloyement }_{i t}+ \\
\beta_{3} R \& D_{i t}+\beta_{4} \text { Corruption }_{i t}+\beta_{6} \text { Uncertainity }+\beta_{7} \text { Regulation }_{i t} \\
\mathrm{t}=1, \ldots, 8 \text { and } \mathrm{t}=1, \ldots, 14
\end{gathered}
$$

MarketCap-market capitalization for each country.

Unemployment-unemployment rate for each country.

R\&D—public expenditure with R\&D.

Corruption-corruption index as provided by cpi.transparency.org.

Uncertainty—the uncertainty index developed by Baker, Bloom and Devis in 2013 [17].

Regulation-represents the perception index of the government's ability to formulate and implement public policies and regulations that would allow for the development of the private equity sector. 
Subsequently, we introduce cross-section fixed effects and cross-section random-effects models. The fixed effects model assumes that all the members of the panel have the same variance and that there is no correlation over time neither across, nor within, the members of the panel. The random effects model assumes that the unobserved effect is uncorrelated with each explanatory variable, and both could randomly vary over time and from one country to another. Jeng and Wells [19] argue that the fixed effect estimation provides the best understanding of the evolution of private equity from one country to another; random effects estimation gives a better understanding of the evolution of private equity over time.

As a quality check, we will run the Hausman specification test in order to compare the consistency of fixed effects models and the random effects models in explaining the sustainability of the private equity market in emerging European countries.

\section{Results and Interpretation}

\subsection{Descriptive Statistics}

Table 4 shows that the level of private equity varies from one country to another, with Poland being the one that benefits from most of the private equity investments, with 4.7 billion euros being invested in this sector over the period 2000-2013. The Baltic States place last in the ranking, with only 633 million euros of private equity investments. According to Appendix A, the average annual value of investments that are made in the private equity market in Eastern Europe is 327 million euros.

Table 4. Descriptive statistics.

\begin{tabular}{cccccc}
\hline & Mean & Maximum & Minimum & Std. Dev. & Observations \\
\hline Unemployment & 0.106630 & 0.206910 & 0.044000 & 0.045015 & 111 \\
\hline Regulation & 1.370176 & 73.45972 & 0.000000 & 6.887816 & 112 \\
\hline R\&D expenditure & 0.008479 & 0.021333 & 0.000000 & 0.004006 & 110 \\
\hline $\begin{array}{c}\text { Private equity } \\
\text { investments }\end{array}$ & 326.9886 & 729.8436 & 0.598000 & 252.2868 & 112 \\
\hline Uncertainty & 127.8876 & 229.0909 & 67.73232 & 46.32270 & 112 \\
\hline Corruption & 0.776786 & 1.000000 & 0.000000 & 0.418272 & 112 \\
\hline Market capitalisation & 2.84 & 2.07 & 5.05 & 4.07 & 104 \\
\hline
\end{tabular}

According to Table 4, the average annual change in the unemployment rate is $10.6 \%$ for the period 2000-2013. However, the unemployment rate reaches its lowest level (4.4\%) during the same period.

\subsection{Correlations}

The correlations that are presented in Table 5 provide an initial overview of the relationship between the macroeconomic variables and the institutional variables used in our econometric model. Correlations between the private equity variable and other explanatory variables range from 0.01 to 0.4 . However, the private equity variable shows higher correlations with the unemployment rate $(0.3)$ and regulation $(-0.3)$.

We have eliminated the risk of "multi-collinearity" because the level of correlations between the explanatory variables is low, i.e., below 0.5 , following the analysis of the matrix of correlations between the variables of our model. Therefore, we did not apply any standard measures to avoid the phenomenon of "multicollinearity" between the values of the exogenous variables of our econometric model. However, the fact that there is a certain level of correlation between the exogenous variables of our econometric model, even if it is weak, is normal, because of the links between the different macroeconomic variables within a given economy. It should be noted that the research that was led by Daude and Stein [27] addresses the issue of "multicollinearity" by grouping the variables that explain the same economic phenomenon. 
Table 5. Correlations Matrix.

\begin{tabular}{cccccccc}
\hline & $\begin{array}{c}\text { Private } \\
\text { Equity }\end{array}$ & $\begin{array}{c}\text { R\&D } \\
\text { Expenditure }\end{array}$ & $\begin{array}{c}\text { Market } \\
\text { Capitalization }\end{array}$ & Unemployment & Uncertainty & Regulation & Corruption \\
\hline Private Equity & 1 & -0.161 & 0.089 & -0.181 & -0.351 & -0.014 & 0.091 \\
\hline $\begin{array}{c}\text { R\&D } \\
\text { expenditure }\end{array}$ & 1 & 0.028 & -0.325 & 0.128 & 0.176 & -0.299 \\
\hline $\begin{array}{c}\text { Market } \\
\text { capitalization }\end{array}$ & & 1 & -0.166 & -0.023 & 0.148 & -0.186 \\
\hline Unemployment & & 1 & 0.024 & -0.194 & 0.242 \\
\hline Uncertainty & & & & 1 & 0.067 & -0.028 \\
\hline Regulation & & & & & 1 & -0.254 \\
\hline Corruption & & & & & & 1 \\
\hline
\end{tabular}

\subsection{Panel Regression Results}

After analyzing the results of Tables 6 and 7, we can conclude that the macroeconomic variables are the ones that most significantly determine the evolution of private equity investments in Eastern Europe. On the other hand, institutional variables, such as uncertainty, corruption, and regulation, also have an impact on the private equity market in Eastern Europe.

Our study shows that market capitalization is a determining factor for private equity in Eastern Europe. It is statistically significant in all estimated models, with both fixed and random effects, as also shown by Black and Gilson [17].

The nature of the relationship between market capitalization and private equity in Eastern Europe is positive and statistically significant for all of the models estimated in Tables 6 and 7, confirming the results of the research of Félix et al. [21]. Therefore, we can conclude that the existence of an active and powerful capital market in Eastern Europe can lead to an increase in the volume of private equity.

The variable unemployment rate that we introduced in both fixed and random effects models has a strong negative impact on private equity investments in Eastern Europe, especially for the fixed effects models.

The conclusion of our research confirms the study that was conducted by Félix et al. [21], since we have shown the existence of a relationship between the labor market in Eastern European countries and the level of development of the private equity market.

Table 6. Empirical results with fixed effects models.

\begin{tabular}{|c|c|c|c|c|c|c|c|}
\hline & \multicolumn{7}{|c|}{ Private Equity } \\
\hline & Model 1 & Model 2 & Model 3 & Model 4 & Model 5 & Model 6 & Model 7 \\
\hline Unemployment & $\begin{array}{l}-986.667 \\
(-3.584)^{* *}\end{array}$ & $\begin{array}{l}-895.386 \\
(-3.235)^{* *}\end{array}$ & $\begin{array}{l}-1164.27 \\
(-3.596)^{* *}\end{array}$ & $\begin{array}{l}-907.263 \\
(-3.306)^{* *}\end{array}$ & $\begin{array}{l}-1189.24 \\
(-3.570)^{* *}\end{array}$ & $\begin{array}{l}-948.240 \\
(-3.390)^{* *}\end{array}$ & $\begin{array}{l}-1235.877 \\
(-3.646)^{* *}\end{array}$ \\
\hline $\begin{array}{c}R \& D \\
\text { expenditure }\end{array}$ & & & & & & $\begin{array}{c}5192.061 \\
(1.030)\end{array}$ & $\begin{array}{c}7463.956 \\
(1.266)\end{array}$ \\
\hline $\begin{array}{c}\text { Market } \\
\text { capitalization }\end{array}$ & $\begin{array}{c}1.19 \\
(4.001)^{* *}\end{array}$ & $\begin{array}{c}1.089 \\
(3.517)^{* *}\end{array}$ & $\begin{array}{c}1.189 \\
(3.361)^{* *}\end{array}$ & $\begin{array}{c}1.079 \\
(3.531)^{* *}\end{array}$ & $\begin{array}{c}1.079 \\
(2.996)^{* *}\end{array}$ & $\begin{array}{c}1.089 \\
(3.406)^{* *}\end{array}$ & $\begin{array}{c}1.041 \\
(2.843)^{* *}\end{array}$ \\
\hline Corruption & & $\begin{array}{c}-41.556 \\
(-1.794) *\end{array}$ & & $\begin{array}{c}-40.304 \\
(-1.754)^{*}\end{array}$ & $\begin{array}{l}-31.388 \\
(-1.244)\end{array}$ & $\begin{array}{l}-31,224 \\
(-1.281)\end{array}$ & $\begin{array}{l}-22.511 \\
(-0.848)\end{array}$ \\
\hline Uncertainty & & & & $\begin{array}{c}0.261 \\
(1.62486)\end{array}$ & $\begin{array}{c}0.322 \\
(1.710263) *\end{array}$ & $\begin{array}{c}0.215 \\
(1.26141)\end{array}$ & $\begin{array}{c}0,281 \\
(1.422)^{*}\end{array}$ \\
\hline Regulation & & & & & $\begin{array}{l}-38.538 \\
(-0.288)\end{array}$ & & $\begin{array}{l}-33.187 \\
(-0.970)\end{array}$ \\
\hline $\begin{array}{l}\text { Adjusted } \\
\text { R-squared }\end{array}$ & 0.922 & 0.924 & 0.911 & 0.925 & 0.915 & 0.923 & 0.912 \\
\hline
\end{tabular}

In the table, the results of fixed effects panel data models are presented. The values of the t-statistics for each variable are presented in parentheses. The $t$-statistics values are significant at the following levels: ** significance at $1 \%$ and * significance at $5 \%$. 
Table 7. Empirical results with random effects models.

\begin{tabular}{|c|c|c|c|c|c|c|c|c|}
\hline \multicolumn{9}{|c|}{ Private Equity } \\
\hline & Model 1 & Model 2 & Model 3 & Model 4 & Model 5 & Model 6 & Model 7 & Model 8 \\
\hline Unemployme-nt & $\begin{array}{l}-958.14 \\
(-3.51)^{* *}\end{array}$ & $\begin{array}{l}-874.684 \\
(-3.176)^{* *}\end{array}$ & $\begin{array}{c}-1125.08 \\
(-3.505)^{* *}\end{array}$ & $\begin{array}{l}-886.844 \\
(-3.24)^{* *}\end{array}$ & $\begin{array}{l}1440.236 \\
(8.301)^{* *}\end{array}$ & $\begin{array}{l}1525.331 \\
(9.449)^{* *}\end{array}$ & $\begin{array}{c}2343.62 \\
(12.97)^{* *}\end{array}$ & $\begin{array}{c}-971.43 \\
(-3.38)^{* *}\end{array}$ \\
\hline $\begin{array}{c}\text { R\&D } \\
\text { expenditure }\end{array}$ & & & & & & $\begin{array}{l}-17,927.8 \\
(-7.98)^{* *}\end{array}$ & & \\
\hline $\begin{array}{c}\text { Market } \\
\text { capitalization }\end{array}$ & $\begin{array}{c}1.219 \\
(-4.03)^{* *}\end{array}$ & $\begin{array}{c}1.089 \\
(-3.54)^{* *}\end{array}$ & $\begin{array}{c}1.201 \\
(3.44)^{* *}\end{array}$ & $\begin{array}{c}1.083 \\
(3.55)^{* *}\end{array}$ & $\begin{array}{c}1.064 \\
(5.642)^{* *}\end{array}$ & $\begin{array}{c}5.051 \\
(2.931)^{* *}\end{array}$ & $\begin{array}{c}6.111 \\
(3.219)^{* *}\end{array}$ & $\begin{array}{c}1.119 \\
(3.581)^{* *}\end{array}$ \\
\hline Corruption & & $\begin{array}{c}-41.4 \\
(-1.79) * \\
\end{array}$ & & $\begin{array}{l}-40.191 \\
(-1.752)^{*}\end{array}$ & $\begin{array}{c}-71.674 \\
(-3.723)^{* *} \\
\end{array}$ & $\begin{array}{c}-129 \\
(-6.977) * *\end{array}$ & $\begin{array}{c}-111 \\
(-5.67)\end{array}$ ** & $\begin{array}{c}-36.2 \\
(-1.543) \\
\end{array}$ \\
\hline Uncertainty & & & & $\begin{array}{c}0.261 \\
(1.628)\end{array}$ & $\begin{array}{c}0.589 \\
(3.206)^{* *}\end{array}$ & $\begin{array}{c}0.420 \\
(2.526)^{* *}\end{array}$ & $\begin{array}{c}0.267 \\
(1.429)\end{array}$ & $\begin{array}{c}0.279 \\
(1.715)^{*}\end{array}$ \\
\hline Regulation & & & & & $\begin{array}{l}-201.540 \\
(-9.05)^{* *}\end{array}$ & & & $\begin{array}{l}-21.298 \\
(-0.895)\end{array}$ \\
\hline $\begin{array}{l}\text { Adjusted } \\
\text { R-squared }\end{array}$ & 0.338 & 0.358 & 0.349 & 0.369 & 0.142 & 0.384 & 0.314 & 0.369 \\
\hline
\end{tabular}

Notes: The values of the t-statistics for each variable are presented in parentheses. The $t$-statistics values are significant at the following levels: ${ }^{* *}$ significance at $1 \%$ and ${ }^{*}$ significance at $5 \%$.

The negative effect of the unemployment rate on private equity in Eastern Europe confirms the fact that private equity investment funds do not worry about the level of the unemployment rate in these countries. Furthermore, this negative relationship shows that an increase in the number of unemployed does not necessarily translate into more entrepreneurs wishing to open their own start-up.

As a result of the estimates that were made in this chapter, we cannot conclude that the R\&D expenditure variable is a driver for the evolution of private equity in Eastern Europe. In most estimated models, this variable has not been statistically validated. The most plausible explanation would be that our R\&D variable does not correctly reflect innovation. In fact, the research of Romain and La Potterie [20] additionally considered the level of R\&D expenditures in the public sector, two new variables in order to capture the effects of innovation, and it was these that showed a positive and statistically significant impact.

We also introduced three institutional variables: corruption, regulation, and the uncertainty index. We consider the first two variables, corruption and regulation, as the binaries (0 or 1).

We can confirm that the corruption is a driving factor for the evolution of private equity and that the corruption negatively influences the decision of a private equity fund to invest in a country in Eastern Europe, according to the results that are presented in Tables 6 and 7. As a result, one of those countries with a high level of corruption will receive a lower level of private equity investments.

Another institutional variable is represented by the regulation, which, to date, has only been statistically validated in the one case of a model with random effects. We cannot say that there is a significant relationship between the government's ability to formulate and implement public policies and regulations and the evolution of private equity in Eastern Europe.

The regulatory variable has been statistically validated in the random effects model, with a $99 \%$ confidence interval. However, the validated relationship is negative, which makes little sense since a private equity investment fund would be more interested in investing in a country where there is a satisfactory level of regulation of the business environment. These results run counter to the existing literature, since Gompers and Lerner [18] cited a positive and statistically significant impact of the level of regulation on private equity in the United States (US).

The uncertainty variable has the most significant impact on the evolution of private equity investments for the random effects models. The relationship between the two variables is paradoxically positive, which contradicts the conclusions of Baker et al. [26], which show that an increase in uncertainty in the United States determines, on average, a reduction in investments in general. 
However, we cannot neglect the fact that the values of the estimated coefficients for both fixed and random effects models are very close to zero. This means that, from an econometric point of view, the impact of the uncertainty variable on private equity is very limited.

\subsection{The Homogeneity Test—Wald Test}

The homogeneity test makes it possible to see whether our model is a usual regression model or a fixed effects model. The results that are presented in Appendix A show the values of the F-Snedecor test and the corresponding probabilities that were obtained after the completion of the Wald homogeneity test. The calculated value of the F test is high and its probabilities are close to zero, which makes us reject the null hypothesis and choose the fixed effects model as being the most appropriate for achieving our regression.

Therefore, we constructed the random effects model from the fixed effects model. In what follows, while using the Hausman test, we will try to understand which of the two models best explains the impact of exogenous variables on the evolution of private equity in Eastern Europe.

\subsection{Robustness-Hausman test}

In this paper, we ran the Hausman specification test in order to compare the consistency of the fixed effects models and random effects models. The null hypothesis of the Hausman test suggests that the coefficients of both estimations with fixed effects, respectively, with random effects that are consistent, but it was found that only the coefficients of the estimation with random effects are more efficient for our model. Hence, the acceptance of the Hausman null hypothesis led us to conclude that the estimation with random effects explains the impact of the independent variables on the evolution of private equity investments in Eastern Europe.

After analyzing the results that were obtained in Appendix B, we can affirm that the estimation with random effects offers the most suggestive probabilities. Therefore, the random effects model allowed for us to validate the majority of the explanatory variables as being statistically significant at different levels of probability. Our econometric simulations allow for us to accept the null hypothesis for most of the models analyzed, which means that the coefficients of the variables of the random effects models are consistent and efficient. We can then notice that for the models: (1); (2); (3); (4); and, (8) the value of the test $\chi 2$ is lower than its theoretical level and the probabilities of the distribution are quite high. It can be concluded that the random effects model offers the best probabilities and allows the explanation of the variables influencing the private equity evolution in Eastern Europe in most cases.

\section{Barriers to Sustainable Private Equity Development and Policy Recommendations}

\subsection{Lack of Exit Mechanisms}

It is very important to provide the possibility of exit routes, such as a liquid stock market, or a dynamic M\&A market, in order to build a private equity ecosystem. Furthermore, the regulations should allow domestic and international capital to flow into and out of companies.

The most active capital markets in Eastern Europe are those of Poland, and then of Hungary and Slovakia. In 2015, the market capitalization of the Warsaw Stock Exchange was larger than Vienna. Despite the crisis, the number of IPOs has steadily increased in recent years in Poland, reaching 872 in 2016. The least active stock markets are those of Ukraine and Lithuania. The liquidity ratio of these stock markets- the volume of trades relative to market capitalization-is less than $11 \%$. In addition, the number of listings to the stock market in Eastern European countries for the period 2000-2014 was 658 in Ukraine, 244 in Latvia, and only 189 in Lithuania.

A recommendation for public policy makers is to take the strategic measures (e.g., the privatization of large state-owned enterprises), regulation measures (e.g., decrease the conditions for listing a company on the stock market), and tax reforms (e.g., lower the tax on re-invested dividends) to develop 
capital markets, because the capital markets could offer attractive divestment opportunities for private equity funds through the listing of the target companies. Thus, the existence of more developed capital markets in Eastern European countries would be proof of a strong economy, a reason that is likely to attract more private equity investments in these countries.

\subsection{Few National Markets Have the Required Sophistication, Scale, and Access}

Few capital markets in Eastern European countries have the sophistication and scale to provide the opportunity for a private equity environment to develop.

The capital markets in Eastern Europe are immature, as market capitalization represents a small percentage of the GDP of these countries. Our empirical model shows that countries with developed capital markets have benefited more from private equity investments. Eastern European governments should move forward in the process of privatizing large state-owned companies in order to increase the size of the capital markets, and one way of achieving this could be listing them on the stock market. Furthermore, governments should attract more investors in their national stock exchange in order to make them more liquid.

\subsection{Labour Market Rigidity and Unemployment}

On the basis of our empirical findings, the unemployment rate had a strong negative impact on the evolution of private equity investments in Eastern Europe. The negative relationship between both of the variables could reflect the fact that an increase in the number of unemployed persons will not translate into an increase in self-employment which, in turn, would have led to an increase in the demand of private equity investments

An important recommendation that could be made is that the lack of employment should be the main concern of policy makers and reversing the unemployment curve should become a priority for any Eastern European government. Private equity investors are very sensitive to the level of unemployment rates in Eastern European countries, according to the results of this research. An increase in the long-term unemployment rate could affect the evolution of private equity investments over a long period of time.

\subsection{Uncertainty and Regulatory Hurdles Can Make the Private Equity Market More Difficult}

According to this research, the uncertainty variable has the most significant impact on the evolution of private equity investments in the case of the random effects models. The uncertainty and regulatory hurdles can take various forms, including a lack of relevant legislation, opacity, or the discretionary nature of existing rules, and over-regulation.

Our recommendation for the policy makers who are interested in facilitating a sustainable development of the private equity market is to benchmark their legal framework against the best practices of the developed private equity markets.

\subsection{The Lack of Compliance and Corruption Are a Strong Burden for Private Equity Firms}

Our econometric results showed that the private equity funds were very sensitive to the existing levels of corruption in Eastern European countries.

\section{Conclusions}

The aim of this research was to identify the main challenges in scaling sustainable private equity markets in emerging Europe. The econometric model covers the period 2000-2013 and 112 observations in 15 Eastern European countries.

We introduced new variables, such as corruption and the uncertainty index that was built by Baker et al. [26]. These variables proved to be important factors in explaining the private equity market in Eastern Europe. 
Among the exogenous variables that we introduce in our model, two macroeconomic variables (market capitalization and unemployment rate) seem to be the most suggestive for explaining the evolution of private equity in Eastern European countries. The nature of the relationship between market capitalization and the private equity market is positive, while the relationship between the unemployment rate and private equity is negative: therefore, the study of the two variables confirms the hypotheses formulated in the literature. Our empirical model shows that countries with developed capital markets benefit more from private equity investments.

According to our empirical analyses, in Eastern Europe we have a sustainable private equity market and we will continue to have one if the private equity funds will continue to consider during the investment process factors, such as unemployment rate and job creation. The private equity funds are also sensitive to the corruption, to the uncertainty, and the regulatory hurdles. Therefore, the private equity funds have incorporated environmental, social, and governance (ESG) factors into the investment decisions.

As described in Figure 2, we have identified the main barriers for developing a sustainable private equity market and we have made the following recommendations for Eastern European governments: they must reduce the unemployment rate, reduce uncertainty in the private equity ecosystem, and facilitate the development of financial markets to attract more private equity investments.

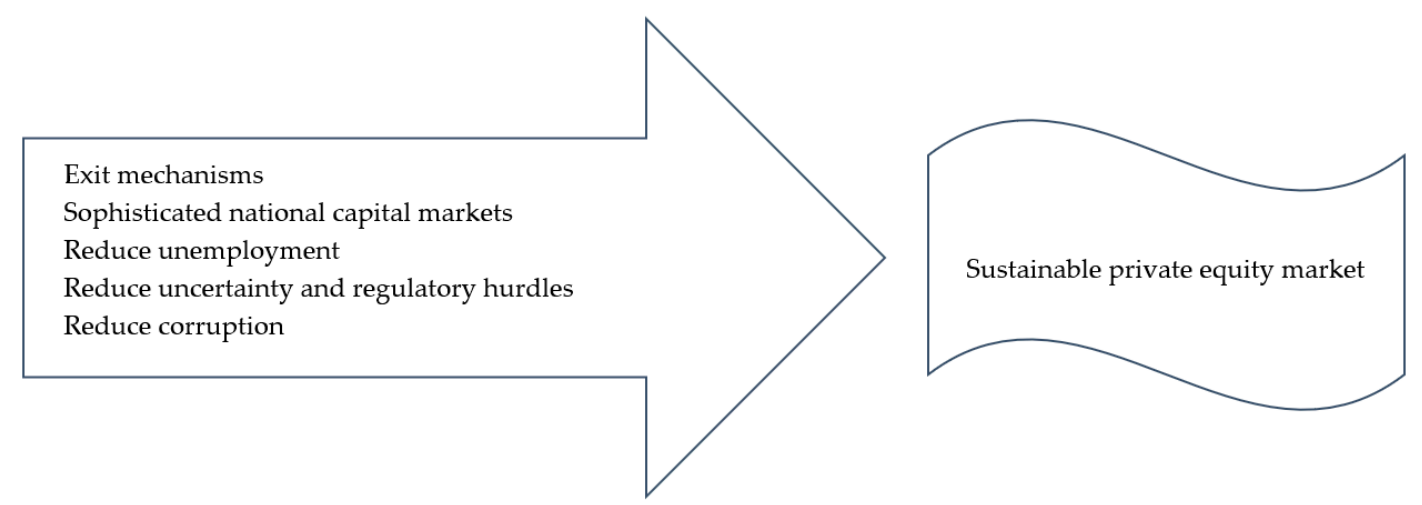

Figure 2. Our recommendations for policy makers.

Funding: This research received no external funding.

Conflicts of Interest: The author declares no conflict of interest.

\section{Appendix A}

Table A1. Estimation Results of the Wald Test.

\begin{tabular}{cccc}
\hline & Value & Degrees of Freedom & Probability \\
\hline F-statistic & 147.2706 & $(7,90)$ & 0.0000 \\
Chi-squared & 1030.894 & 7 & 0.0000 \\
\hline The results of the null hypothesis & Value & Standard Error \\
\hline \multicolumn{2}{c}{ Coefficient (8) } & -587.7727 & 31.95472 \\
Coefficient (9) & -639.6487 & 35.35097 \\
Coefficient (10) & -619.3645 & 38.86281 \\
Coefficient (11) & -356.3877 & 50.80957 \\
Coefficient (12) & -301.6051 & 29.66473 \\
Coefficient (13) & -151.9161 & 43.35768 \\
Coefficient (14) & 16.93535 & 41.33823 \\
\hline
\end{tabular}




\section{Appendix B}

Table A2. Hausman test estimations.

\begin{tabular}{|c|c|c|c|c|c|c|}
\hline Model & Variables & $\begin{array}{c}\text { x2 Estimated } \\
\text { Value Hausman }\end{array}$ & $\begin{array}{l}x^{2} \text { Critical } \\
\text { Value }\end{array}$ & Probability & $\begin{array}{l}\mathrm{H} 0 \text { or } \mathrm{Ha}{ }^{*} \\
\text { Validated }\end{array}$ & $\begin{array}{l}\text { Estimation } \\
\text { Efficient }\end{array}$ \\
\hline 1 & $\begin{array}{l}\text { Market capitalisation } \\
\text { Unemployment }\end{array}$ & 3.4 & 7.8 & 0.33 & HO & $\begin{array}{c}\text { Random } \\
\text { effects }\end{array}$ \\
\hline 2 & $\begin{array}{l}\text { Market capitalisation } \\
\text { Unemployment } \\
\text { Corruption }\end{array}$ & 2.6 & 9.488 & 0.6263 & $\mathrm{H} 0$ & $\begin{array}{l}\text { Random } \\
\text { effects }\end{array}$ \\
\hline 3 & $\begin{array}{l}\text { Market capitalisation } \\
\text { Unemployment }\end{array}$ & 4.36 & 9.488 & 0.3593 & $\mathrm{H} 0$ & $\begin{array}{c}\text { Random } \\
\text { effects }\end{array}$ \\
\hline 4 & $\begin{array}{l}\text { Market capitalisation } \\
\text { Unemployment } \\
\text { Corruption } \\
\text { Uncertainty }\end{array}$ & 0 & 11.07 & 1 & $\mathrm{H} 0$ & $\begin{array}{c}\text { Random } \\
\text { effects }\end{array}$ \\
\hline 5 & $\begin{array}{l}\text { Market capitalisation } \\
\text { Unemployment } \\
\text { Corruption } \\
\text { Uncertainty } \\
\text { Regulation }\end{array}$ & 739 & 14.067 & 0 & $\mathrm{Ha}$ & Fixed Effects \\
\hline 6 & $\begin{array}{l}\text { Market capitalisation } \\
\text { Unemployment } \\
\text { Corruption } \\
\text { Uncertainty }\end{array}$ & 677.21 & 14.067 & 0 & На & Fixed Effects \\
\hline 7 & $\begin{array}{l}\text { Market capitalisation } \\
\text { Unemployment } \\
\text { Corruption } \\
\text { Uncertainty }\end{array}$ & 564.4483 & 14.067 & 0 & $\mathrm{Ha}$ & Fixed Effects \\
\hline 8 & $\begin{array}{l}\text { Market capitalisation } \\
\text { Unemployment } \\
\text { Corruption } \\
\text { Uncertainty } \\
\text { Regulation }\end{array}$ & 0 & 14.067 & 1 & $\mathrm{H} 0$ & $\begin{array}{l}\text { Random } \\
\text { effects }\end{array}$ \\
\hline
\end{tabular}

\section{References}

1. European Venture Capital Association. European Private Equity Activity 2017. Available online: www.evca. eu (accessed on 15 January 2019).

2. Patrick, A. Les fonds de private equity, Revue d'économie financière; Association d'économie financière: Arcueil Cedex, France, 2008; pp. 9-12.

3. Ljungqvist, R.; Richardson, M. The Cash Flow, Return and Risk Characteristics of Private Equity. NYU, Finance Working Paper No. 03-001. 18 March 2003, pp. 1-43. Available online: https://papers.ssrn.com/sol3/papers. cfm?abstract_id=369600 (accessed on 8 July 2019).

4. Phalippou, L.; Gottschalg, O. The performance of private equity funds. Rev. Financ. Stud. 2008, 22, 1747-1776. [CrossRef]

5. Harris, R.S.; Jenkinson, T.; Kaplan, S.N. Private equity performance: What do we know? J. Financ. 2013, 69, 1851-1882. [CrossRef]

6. European Venture Capital Association. 2013 Pan-European Private Equity Performance Benchmarks Study. Available online: www.evca.eu (accessed on 15 January 2019).

7. Kevin, R. Why new issues are underpriced. J. Financ. Econ. 1986, 15, 187-212.

8. Amit, R.; Brander, J.; Zott, C. Why do venture capital firms exist? Theory and Canadian evidence. J. Bus. Ventur. 1998, 13, 441-466. [CrossRef]

9. Cumming, D.; MacIntosh, J. Venture capital exits in Canada and the United States. J. Univ. Tor. 2003, 53, 101-200. [CrossRef]

10. The Exit Decision in the European Venture Capital Market. CEFAGE-UE Working Paper. February 2008, pp. 5-24. Available online: https://core.ac.uk/download/pdf/7094641.pdf (accessed on 15 January 2019). 
11. Cumming, D. Preplanned exit strategies in venture capital. Eur. Econ. Rev. 2008, 52, 11-40. [CrossRef]

12. Smith, N.C. Morality and the Market: Consumer Pressure for Corporate Accountability; Routledge: London, UK, 1990; pp. 301-351.

13. Kaplan, S.N.; Sensoy, B.A.; Strömberg, P. Should investors bet on the jockey or the horse? Evidence from the evolution of firms from early business plans to public companies. J. Financ. 2009, 64, 75-115. [CrossRef]

14. Kearney, A.T. Creating New Jobs and Value with Private Equity; AT Kearney: Chicago, IL, USA, 2007; pp. 45-71.

15. Engel, D.; Keilbach, M. Firm-level implications of early stage venture capital investment-An empirical investigation. J. Empir. Financ. 2007, 14, 150-167. [CrossRef]

16. Bertoni, F.; Colombo, M.G.; Grilli, L. Venture capital financing and the growth of high-tech start-ups: Disentangling treatment from selection effects. Res. Policy 2011, 40, 1028-1043. [CrossRef]

17. Black, B.S.; Gilson, R.J. Venture Capital and the Structure of Capital Markets: Bank versus Capital Markets. J. Financ. Econ. 1998, 47, 243-277. [CrossRef]

18. Gompers, P.; Lerner, J. What Drives Venture Capital Fundraising? Brooking Papers on Economic Activity. Macroeconomics 1998, 149-192. [CrossRef]

19. Jeng, L.; Wells, P. The Determinants of Venture Capital Funding: Evidence Across Countries. J. Corp. Financ. 2000, 6, 241-289. [CrossRef]

20. Romain, A.; de la Potterie, B.V.P. The Determinants of Venture Capital: A Panel Data Analysis of 16 OECD Countries; Research Institute in Management Science: Wuhan, China, 2004; pp. 10-35.

21. Felix, E.; Gulamhussen, M.A.; Pires, C.P. The Determinants of Venture Capital in Europe Evidence across Countries. CEFAGE-UE Working Paper. January 2007, pp. 11-25. Available online: https:/www.semanticscholar.org/paper/CEFAGE-UE-Working-Paper-2007-\%2F-01The-Determinants-F\%C3\%A9lix-Gulamhussen/71753045b2ee317fe338658eb4a4c4a18d83152b (accessed on 8 July 2019).

22. Bernoth, K.C. The macroeconomic determinants of private equity investment: A European comparison. Appl. Econ. 2014, 56, 1170-1183. [CrossRef]

23. Karsai, J. The End of the Golden Age-The Developments of the Venture Capital and Private Equity Industry in Central and Eastern Europe. IEHAS Discussion Papers 0901. 2009, pp. 60-91. Available online: https: //ideas.repec.org/p/has/discpr/0901.html (accessed on 8 July 2019).

24. Moldovan, N.; Vătavu, S.; Albu, C.; Stanciu-Mandruleanu, C.; Panait, R. Corporate Financing Decisions and Performance in Times of Crisis: Threat or Challenge? Econ. Comput. Econ. Cybern. Stud. Res. 2016, 50, 59-79.

25. Diaconu, M. Private Equity Market Developments in Central and Eastern Europe. Theor. Appl. Econ. 2017, 24, 131-146.

26. Baker, S.R.; Bloom, N.; Davis, S.J. Measuring Economic Policy Uncertainty. Q. J. Econ. 2013, 131, 2-26. [CrossRef]

27. Daude, C.; Stein, E. The quality of institutions and foreign direct investments. Econ. Politics 2007, 19, 317-343. [CrossRef]

(C) 2019 by the author. Licensee MDPI, Basel, Switzerland. This article is an open access article distributed under the terms and conditions of the Creative Commons Attribution (CC BY) license (http://creativecommons.org/licenses/by/4.0/). 